\title{
Hussaini \\ The Influence of the Sectarian Doctrine on the Architecture of the Shi'a Mosques in Iran
}

\author{
Ghada Abdel Monem El Gemaiey \\ Islamic Archeology, Faculty of archeology, Cairo university, Egypt
}

\begin{abstract}
This research is concerned with the influence of the Shi'a sectarian doctrine on the appearance of a new kind of mosques that was only known in the Shi'a Islamic world, the models of which reached Iran and Iraq. In fact, it is known that the appearance of the architecture of mosques was directly related to the Muhammadian Call and the rise of Islam before the establishment of the Prophet (pbuh) Mosque. On the other hand, the appearance of Hussaini in the $4^{\text {th }}$ Century A.H. was directly related to the political circumstances of the Abbasid State at that time. Later on, Hussaini buildings were intermittently established in relation to the governments and the ruling systems of the Islamic world, with their intellectual and sectarian tends. However, they spread in the Safavid and Qajared Eras in Iran, and the Safavid Age in Iraq, especially Shah Abbas I in 995-1038 A.H. / 1587-1629. As for the main factor that influenced the architecture of such mosques, it is the sectarian factor that is related to the Shiite intellect, corners and main branches, which of course differs from one sect to another depending on the diverse and spreading Shi'a ideologies. Since this research is mainly concerned with the Hussaini architecture in Iran, the focus will be on the influence of the Shiite sectarian thought of the Twelver on the former. It also refers to the differences between the horizontal plan, the units and the elements of the architecture of such mosques and that of the main mosques spreading in Islamic world, which are related to all the Muslims with their different ideologies. Moreover, the research will reveal the connection between such differences and the function of the Shiite mosques. Finally, it will shed light on the technical units and elements of symbolic significance that decorate the corners and angles of Hussaini buildings from the inside and sometimes on the outside, and how they directly and bluntly relate to the Shiite thought.
\end{abstract}

Keywords: Al-Hussain, Isfahan, Iwan, Nain, Tehran.

\section{Introduction}

This introduction includes the history of Hussaini architecture in the Islamic world, the reasons for its appearance, and its influence with the Shi'a thought. Before speaking about the history of Hussaini architecture [1], a clear definition of Hussaini تكية [2] is given to avoid any confusion between the former and Hospice [3], Boca'a بقعة / Spot [4], Sanctuary مانقاه [6], Imam Zadh مام زاده [6], and Chapel even according to the Iranian historian or archeologist [8]. In fact, such buildings are all sectarian, specialized mostly in the Shi'a doctrine functions and practices. Some Iranian archeologists confuse between these sectarian buildings, which is widely agreed upon, and the architecture of mosques and schools, which are also regarded as sectarian buildings in which Shiite ceremonies are practiced in feasts and specific celebrations. Accordingly, Hussaini buildings are places for religious condolences "mourning" [9], which is the ceremony of demonstrating the death of al-Hussain (May Allah be pleased with him) in private vast areas. As a matter of fact, Hussaini buildings are specifically established for this purpose (1, pp. 74-79).

\section{I.1 The History of Hussaini}

In the Safavid Age, the condolences along with the Hussaini got to be known, especially in small towns and villages. Then, they spread not only in Iran, but also all around the Shi'a Islamic world. They developed in Iran during the era of Karim Khan, as they became distinguished in representation resembling alHussain, his family and the military of opposition. In the age of Naser al-Din Khan, they developed to resemble the theatrical formation, along with the European effects and the theatrical principles competence, which are seen in religious performances on stage (2, p. 23). In such condolences, each participant plays a role and wears special costume to set the scene. This is accompanied by martial tools like a spear, sword, shield, dagger, bagpipe and horse, and sound effects of drums, trumpet, and flute. Usually, the condolences derived their artistic characteristics from Tartuffe, elegies, praise and merits, in which such elegies are mostly poetic verse, read in special rhythm (3. Pp. 96-98). The term Hussaini refers to al-Hussain (pbuh), and is known after his name [10]. Despite the fact that the beginning of the establishment of Hussaini was in the Safavid Era, they 
started spreading in the Qajared Age, as many of them were found from this Era, with diverse architectural plans and miniatures.

\section{I.2 The Function of Hussaini Buildings:}

Hussaini buildings are of major importance to Shiite, coming directly after mosques. However, they do not require the same regulations of entering a mosque, and they mainly appeared with Imams after Karbala War to reflect the tragedy of al-Hussain and his family [11]. Despite the practice of dissimulation at that early stage in fear of the Umayyad violence against the blessed ancestors, they acted the war scenes for those who did not witness it to benefit from it. In fact, this was all kept a secret from the rulers of the Umayyad and early Abbasid Ages. However, with the rise of sectarian and ethnic nationalities, and the division of the Islamic world in the Abbasid Age among the provinces and territories princes, the ruling Shi'a states appeared like the Buyid State in some Iranian cities, spreading their own doctrine. Yet, back then, the Hussaini were not yet known, but were there for lamenting, crying and slapping [12]. Shi'a historians regard al-Hussain to be the first to weep, lament and mourn himself on the fourth of Moharram شهر محرم, which is six days before his death, as he brought his family of forty men, women and children all together, and kept crying when the horrors of the tenth day appeared to him; that thirty of Prophet Muhammad (pbup) ancestors of men, women and children would be killed (4. pp. 73-74).

The condolences were made in hospices and Khanqah (colleges), so as not to annoy the Abbasid Caliphs, and Sunny whom where lived there for a long time. This continue till Iran was announced a Shi'a State at the age of Shah Ismail I (5. s.1, pp. 46-47). Sometimes, the public squares were used as Hussaini after adding some objects that have sectarian symbols related to Ashura Day يوم عانشوراء, as well as in the spacious halls of the hospices (6.pp, 165-168).

\section{Hussaini Buildings Locations}

The Hussaini buildings are usually established on the borders or edges of the cities and villages, in which certain factors are taken into consideration determining their spread. In the Safavid Age, the city was divided into the city center that is surrounded by shops through empty streets connected together by alleys and lanes, in addition to two main squares, one of which is a public commercial or governmental square and the other is a hospice or Hussaini building [13], as in Semnan, Yazd, Tehran, Nain and other Iranian cities (Fig.1). The space of Hussaini is determined according to the population in the area to serve the whole community.
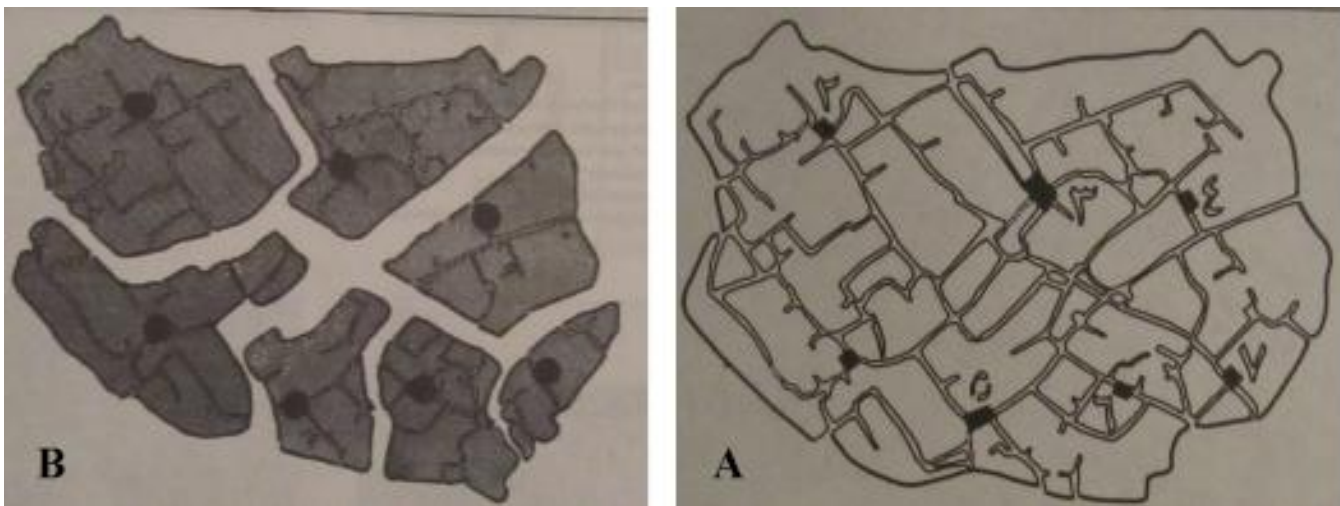

Fig (1) Nain City: A. shows the distribution of Hussaini buildings inside the city, B. shows the relation between the area space and the Hussaini distribution (7. Pp. 99-130)

\section{An Archeological Architectural Study Of The Iranian Hussaini Models In The Safavid Era:}

Hussaini buildings are divided into ones attached to imam Zadh and others sectarian buildings inside the city, following a religious community or separate Hussaini buildings with certain units and extensions. Such buildings are established at the city borders. Among the buildings that are established as extensions to the Hussaini buildings, either attached or separated, is Saqakhana "Sabil", as a reminder of thirst and pain, or they may be distributed around with water sinks their sides like Sengap or containers like Ab Anbar connected to them through channels, as in Nokapad Hussaini or inside them as in Kelwan, Bab al-Masjid, and Saray No Hussaini (7.pp.134). This is in addition to a mosque for the five prayers "Namazkhana", and finally a kitchen to prepare the food for the religious ceremonies. Hussaini buildings spread in Iran in the Safavid Age since the state declared Shi'a as the official doctrine, as it also spread in Iraq, especially at the time of Shah Abbas during his victory over the Ottomans. The Hussaini buildings appeared as well in India and Middle Asia, during the Safavid Age, in which their artistic and architectural features were influenced by the Persian art and architecture throughout history. 
Many horizontal plans used by architects in establishing Iranian Hussaini were received, as there were Hussaini buildings with square of rectangle horizontal plans, along with octagonal horizontal shape, and sometimes circular. Most Hussaini buildings consist of two floors. However, some exceptions of such design were received, like ones with one floor or several floors (three floors). As an example of this is Tehran Hussaini that Naser al-Din Shah ordered its establishment in 1290A.H. / 1873A.D. for being influenced by the European theatrical thought, and was known as the government hospice. It consists of several floors; the first floor is an empty space centered with a gypsum building in which elegies and epic poems were presented. The rest of the floors were occupied with a group of rooms in a rectangle horizontal plan, for the residence of the Shah and his family, the poets and imitators [14].

As for the Hussaini architecture styles, they have an iwan design consisting of one, two or four iwans. In fact, it is similar to the architecture of the Safavid mosques and schools, which had the iwan design as their official one. Yet, the difference between them lies in that the mosque and school had a unity of corridor, while this never appeared in Hussaini architecture. The following part presents the patterns and styles of Iranian Hussaini buildings, divided into two main patterns; the first is the separate Hussaini and the second is the attached with architectural groups, in which such architectural extensions and units attached are subsequent or prior to the Hussaini establishment. Each pattern is explained as follows.

\section{The First Pattern: The Separate Pattern:}

This separate pattern of Hussaini relates to the ones built alone without any architectural extensions or units attached to it for different functions. Such Hussaini buildings were built for the main function of giving condolences on Ashura Day. Three styles of this pattern were received, depending in their division on the Number of iwans distributed into the Hussaini sides on the inside, as follows:

\section{IV.1 The First Style: The four-iwan Hussaini style:}

In its horizontal plan, it depends on four iwans in the middle of the Hussaini sides on the inside, filling the confined sides within the iwans with a Number of opaque or open entrances that lead to the chambers, among which are:

\section{IV.1.1 Echthard Hussaini اشتهارد حسينية :}

It is located in "Karaj Echthard" in Tehran, dating back to the Safavid Age (8. P. 139). It consists of an open square-shaped centered court, with almost rinsed corners decorated by a group of extensions (Fig.2). In the middle of the court sides are four iwans that completely open to the court space. The deepest of iwans is the main one, upon which sides are two chambers that completely open to the court space, extending as the main iwan, faced by an entrance iwan. The Hussaini has two entrances of a distinguished design, in which the iwan is attached to an entrance vestibule of an octagonal horizontal plan opening to the street through a spacious door. On both sides of the iwan entrance, there are two chambers; one on the left and the other on the right, with a rectangular horizontal plan. On the other side, the western southern side has the second Hussaini entrance that opens on rectangular horizontal chambers that lead to the second floor, while the opposite side has a group of connected chambers, entered through three opaque entrances, the widest of which is the iwan entrance.

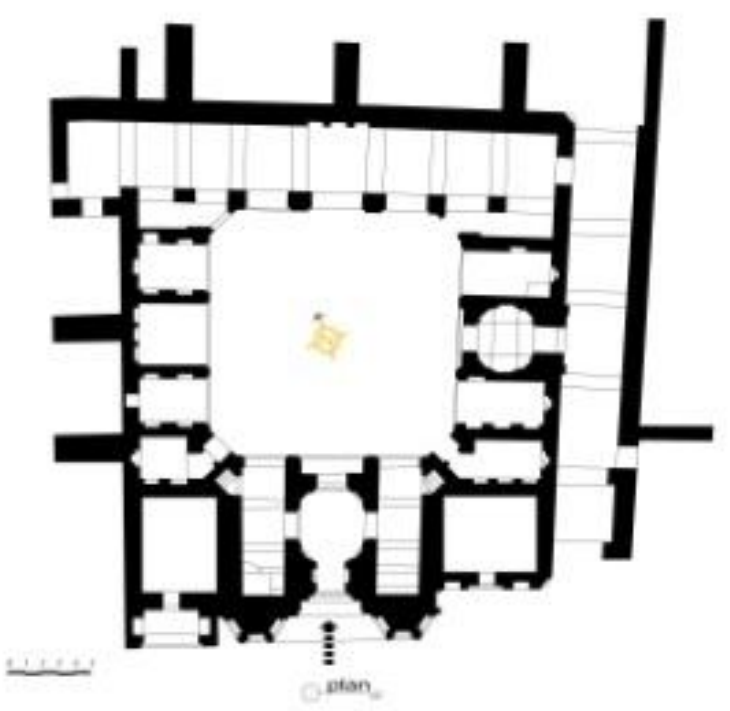


Fig (2) Echthard Hussaini: A horizontal plan (By the researcher)

\section{باب المسجد حسينية:IV.1.2 Bab al-Masjid Hussaini}

It is located in Nain in the Darb Masjid locality, dating back to the Qajared Age (8. P.139).It consists of an open centered court (Fig.3). in the middle of which sides are four iwans that completely open to the court space. It has two floors, each of which has several chambers. The main iwan and the one opposite to it open to the court with three opaque entrances of sharpened edges, the widest and highest of which is the middle one. The main iwan is covered by a high dome with long neck similar to Samarkand domes. The chambers are covered by small lobed domes. In the opposite sides, the iwan opening completely opens to the court, with quinary horizontal plan, shrouded on the right and left by four entrances; two on each side, one of which opens on the whole court functioning as a Hussaini entrance.

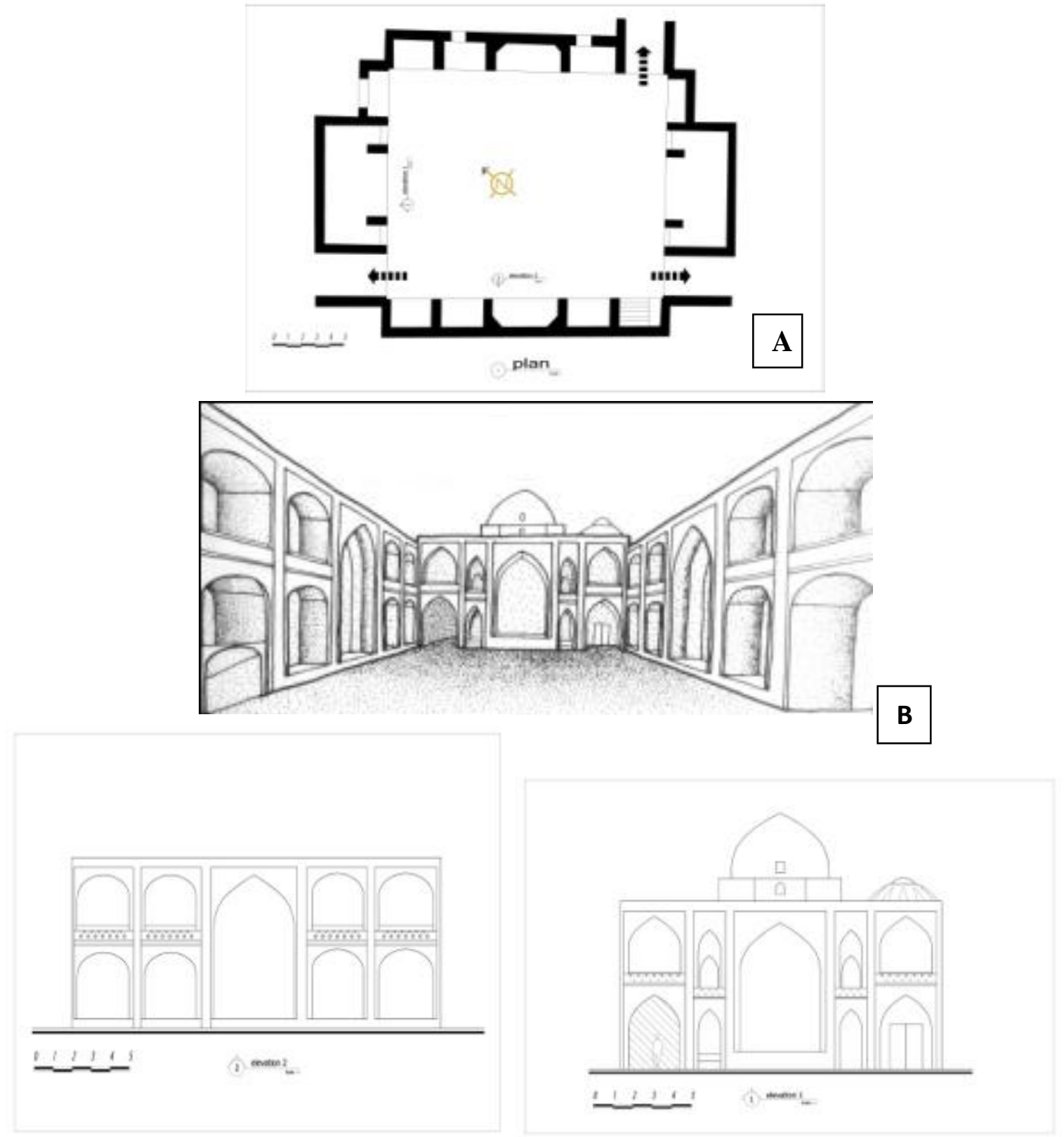

Fig (3) Bab al-Masjid Hussaini: A. A horizontal plan, B. A perspective of the Hussaini interfaces showing the floors, varying between plain entrances and others leading to chambers (By the researcher) 


\section{IV.2 THE SECOND STYLE: THE TWO-IWAN HUSSAINI STYLE:}

Its horizontal plan depends on an open centered court, in which the two main sides have opposite iwans, while the other sides have a group of opaque entrances with edged solid side through which the chambers are entered and in which there are private entrances to the Hussaini.

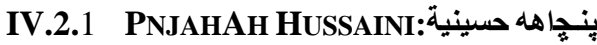

It is located in Nain city in Nokapad locality, dating back to the Qajared Age (8. P.139). It is a square horizontal plan centered by an open court (Fig.4), on which sides there are two iwans that are wider and higher than the rest of the chambers. One of these iwans is distinguished by being divided into two floors and does not completely open to the court, leading directly to the Hussaini entrance. On the other hand, the other iwan opens completely to the court. The two sides have a group of five opaque entrances, some of which are plain while others lead to the chambers. One of the main entrances of the two floor Hussaini, directly opening to the court, is covered by a dome with a lantern.

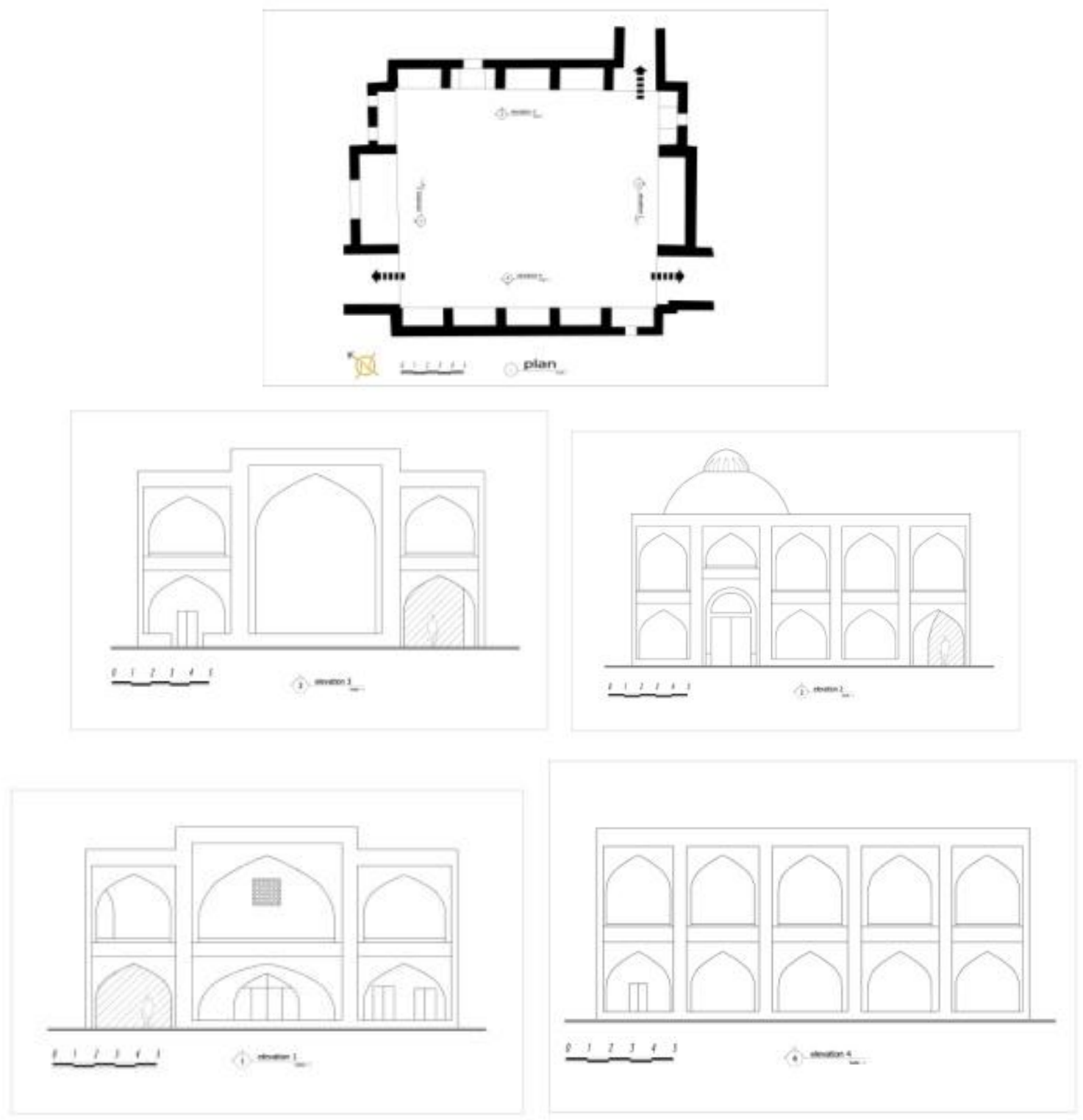

Fig (4) Pnjahah Hussaini: A horizontal plan and sectors "sections" of the Hussaini interfaces on the inside (By the researcher)

\section{سنگ حسينية:IV.2.2 Sanag Hussaini}

It is located in Nain in Sanag "Kodalo" locality, dating back to the Qajared Age (8. P. 139), (7. P 122). It has a rectangle horizontal plan, in which the court occupies a big space (Fig. 5). One of the sides has two iwans; one of which completely opens to the court, while the other is divided into two opaque entrances. 
The other sides have opaque entrances, some of which are plain while others lead to small chambers. One of the main entrances of the two floor Hussaini, directly opening to the court, is covered by a dome with a lantern.
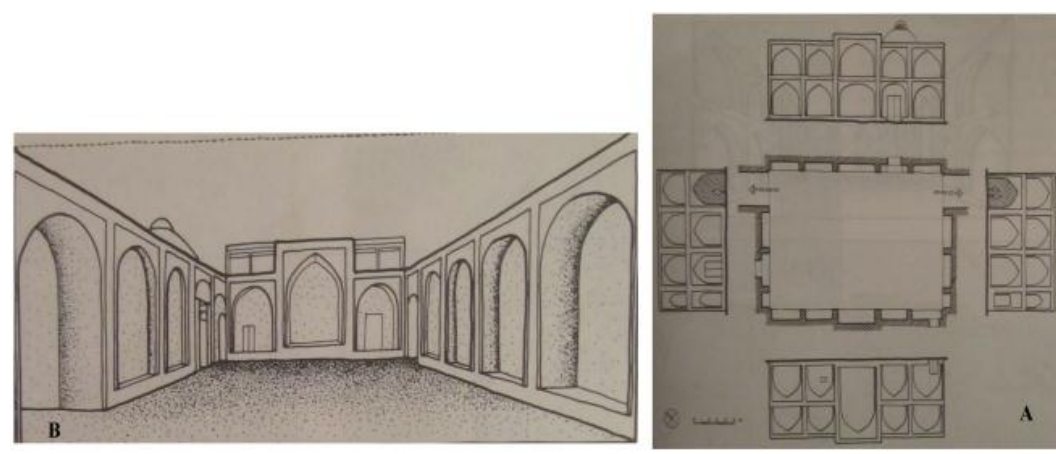

Fig (5) Sanag Hussaini: A. A horizontal plan of the interface, B. A perspective of the Hussaini interfaces from the inside, showing the inconsistency in the sides (7.pp. 123-124)

\section{IV.3 THE THIRD STYLE: THE ONE-IWAN HUSSAINI STYLE:}

Its horizontal plan consists of an open centered court, in which the main side has one iwan only, while the other sides have a group of opaque entrances with edged solid side through which the chambers are entered and in which there are private entrances to the Hussaini.

\section{Sلوان حسينية:IV.3.1 Kelwan Hussaini}

It is located in Nain in Kelwan locality, dating back to the Qajared Age (8.p. 139). In the middle of the court, a lantern has been recently added and the Hussaini is made of two floors. The horizontal plan of it consists of an open centered rectangular court, in which the western southern side has the main iwan that completely opens to the court, while the rest of the sides and the left and right of the iwan are surrounded by a group of chambers of a rectangular horizontal plan. The court open to three entrances and the middle of the western northern side is covered by a dome with a lantern.

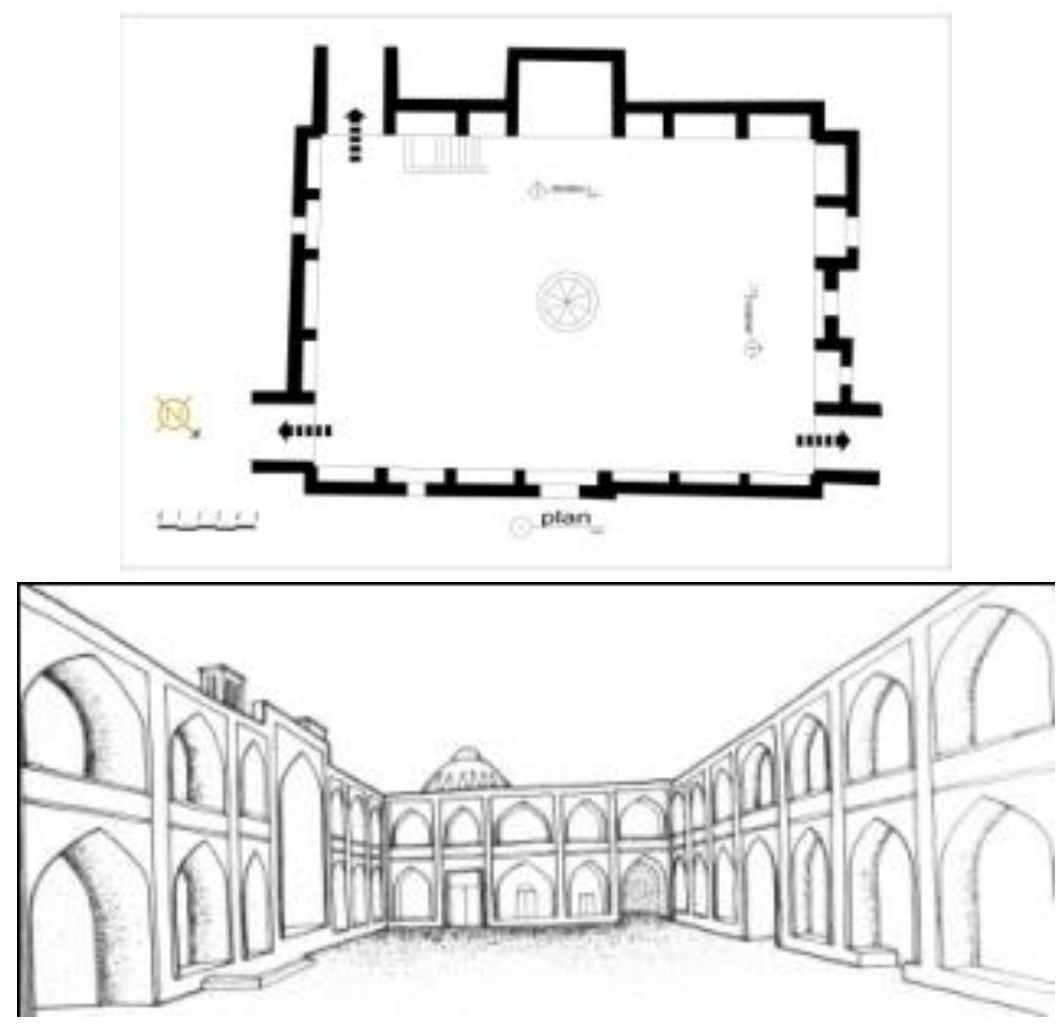



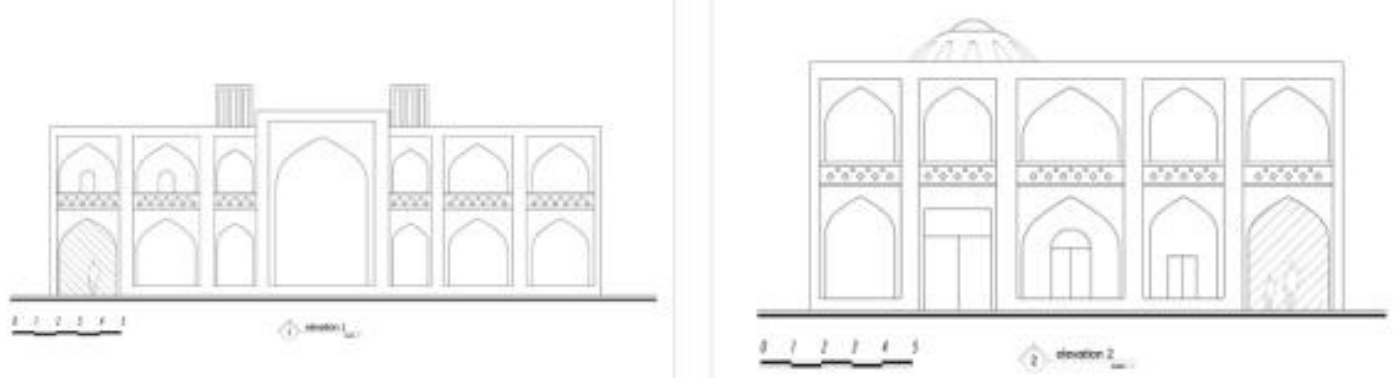

Fig (6) Kelwan Hussaini: A horizontal plan of the main interface with another side one. A perspective of the Hussaini interface from the inside, showing the consistency in the sides and its coverage by a dome with a lantern. A vertical plan of the main interfaces. (By the researcher)

\section{IV.3.2 Nokapad Hussaini نو كاباد حسينية}

It is located in Nain city in Nokapad locality, dating back to the Qajared Age (8.p. 139). It is a rectangular horizontal plan centered by a big open court (Fig 7), in which one of its sides has a deep iwan. The other sides have opaque entrances, some of which are plain while others lead to chambers of a rectangular horizontal plan. The Hussaini consists of one floor only, with seven entrances, the main of which is covered by a dome with a lantern.
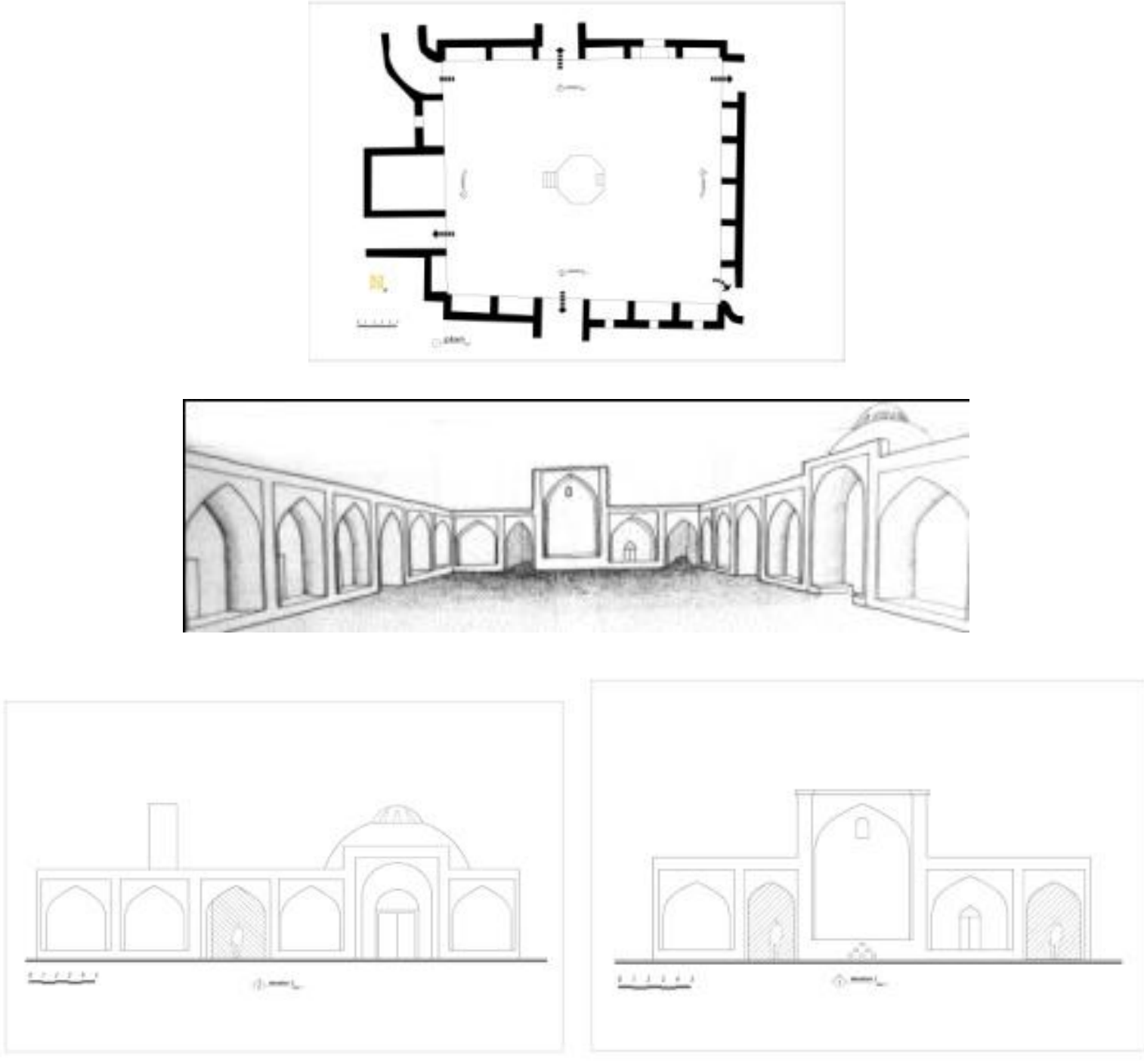

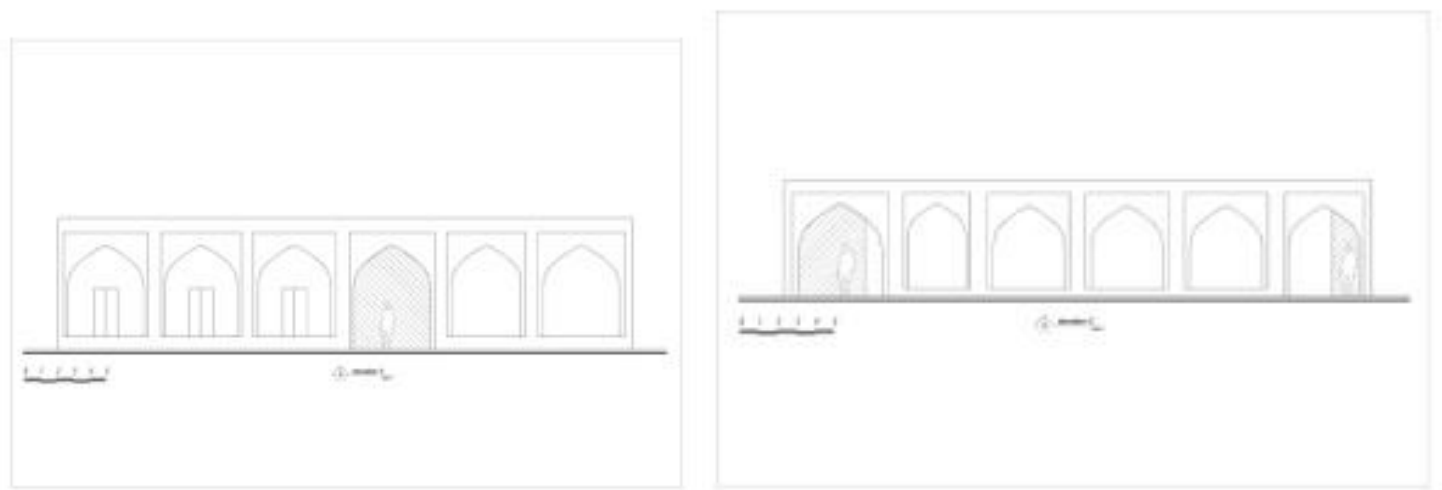

Fig (7) Nokapad Hussaini: A horizontal plan of the Hussaini and its interfaces. A perspective of the Hussaini interfaces from the inside, showing its coverage by a dome with a lantern along with the inconsistency of its internal interfaces. A vertical plan of the interfaces from the inside. (By the researcher)

\section{سراي نو حسينية:IV.3.3 Saray No Hussaini}

It is located in Nain city in No locality, dating back to the Qajared Age (8. P. 118). It is a rectangular horizontal plan centered by a centered open court, in which its western southern side is centered by a high iwan with two chambers on the sides (Fig.8); one on the left and the other on the right. The other sides have opaque entrances, and the Hussaini consists of one floor only, in which one of the entrances is covered by a dome with a lantern.

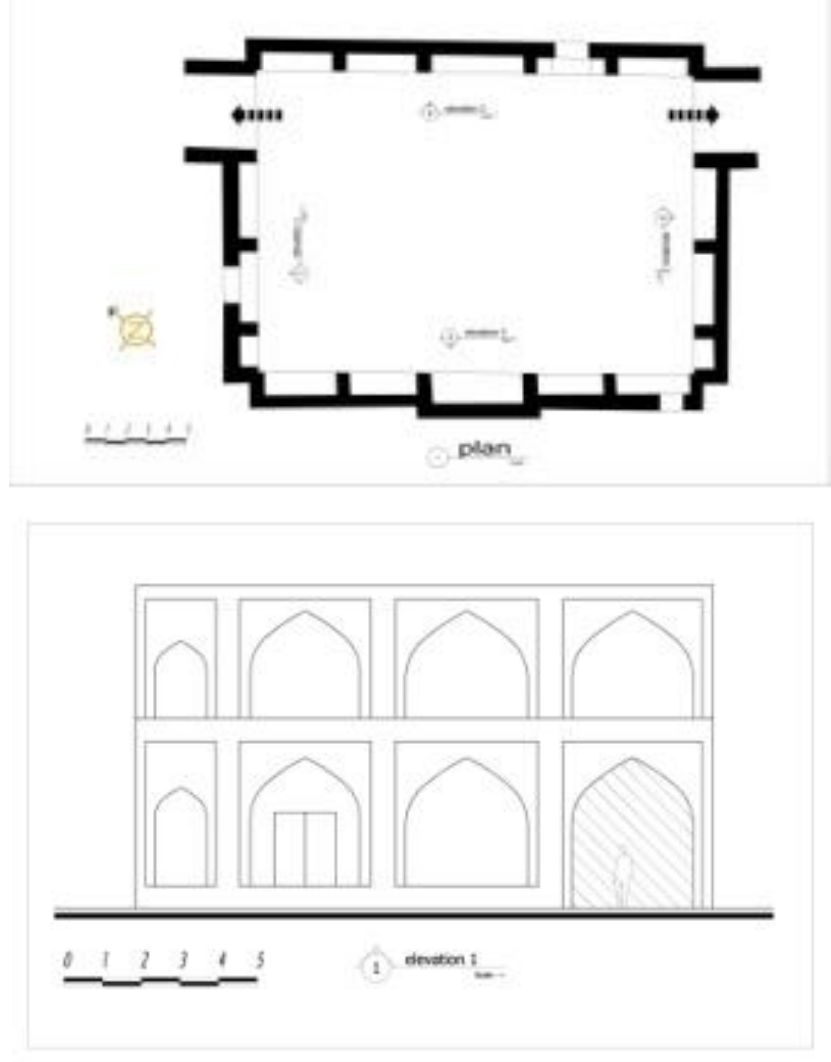



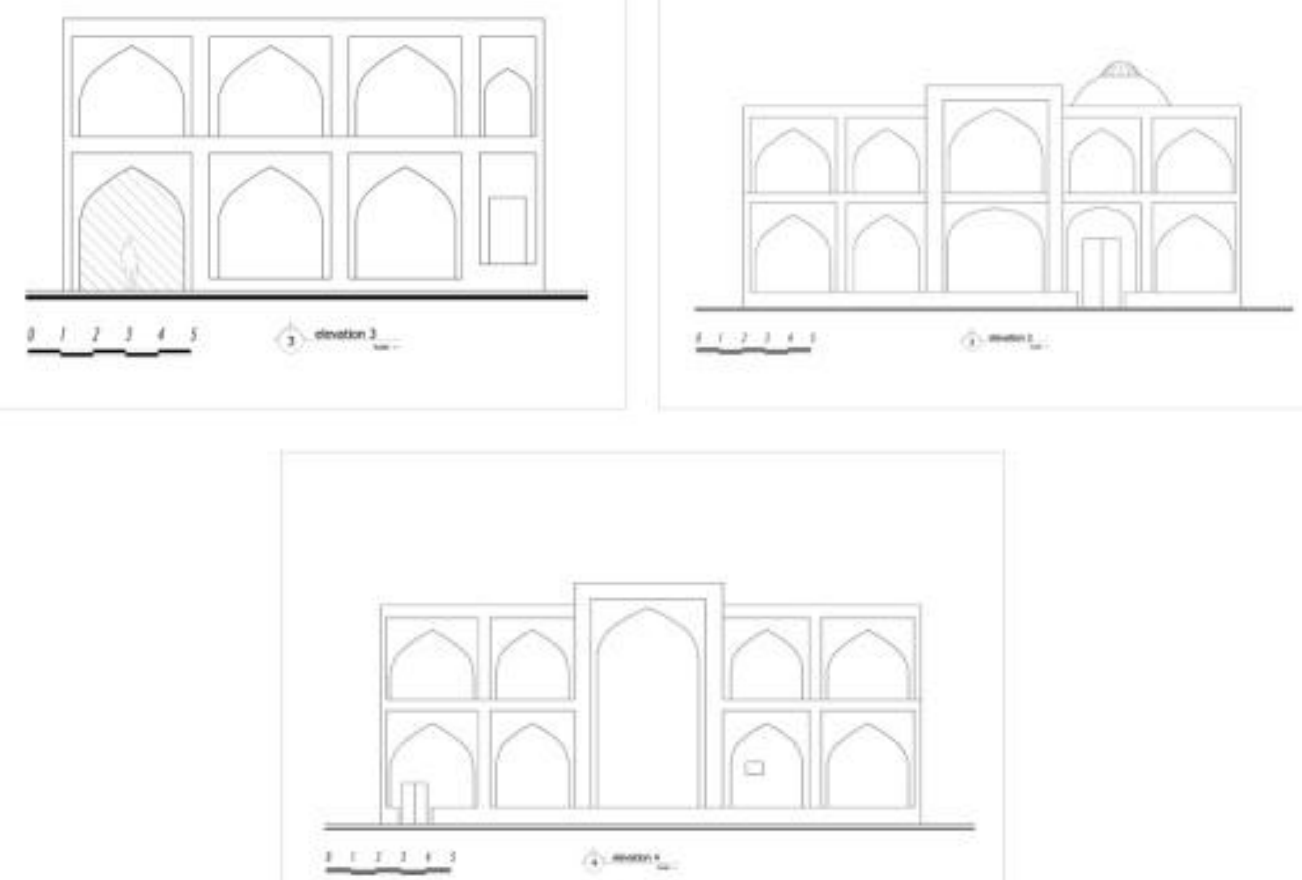

Fig (8) Saray No Hussaini: A horizontal plan of the Hussaini and its main interfaces from the inside.

(By the researcher)

\section{IV.3.4 Jahl Dokhtaran Hussaini : جهل دختران حسينية}

It is located in Nain city in Jahl Dakhetan locality, dating back to the Qajared Age (8.p.139). It has a square horizontal plan with the court taking more than half of its space (Fig.9). The eastern northern side is centered by an iwan that opens completely to the court, while the other sides have opaque entrances. This Hussaini has many features despite its small space, as in the eastern northern side there is a panorama (16) as the one in Iranian mosques and schools. Also, in the western southern side, there is a tower similar to the Syrian minarets, with a square vertical plan in which its final third is divided and carved, known as Padcar (17), providing good airing for the Hussaini heat. It is worth noting that the panorama and the tower are on the same line. Thus, this Hussaini combines between two architectural units; one of mosques and the other of civil architecture.
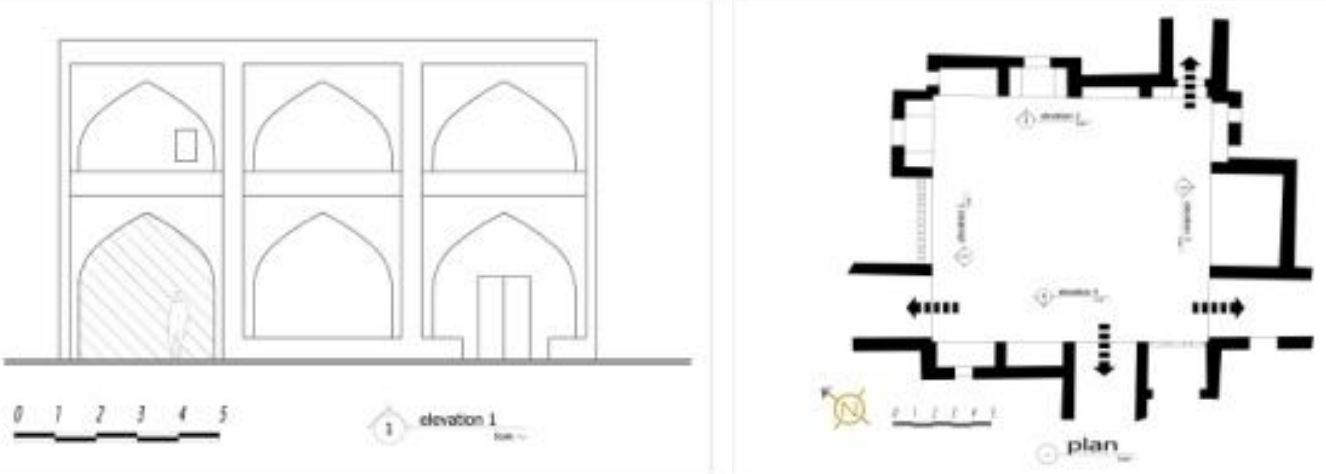


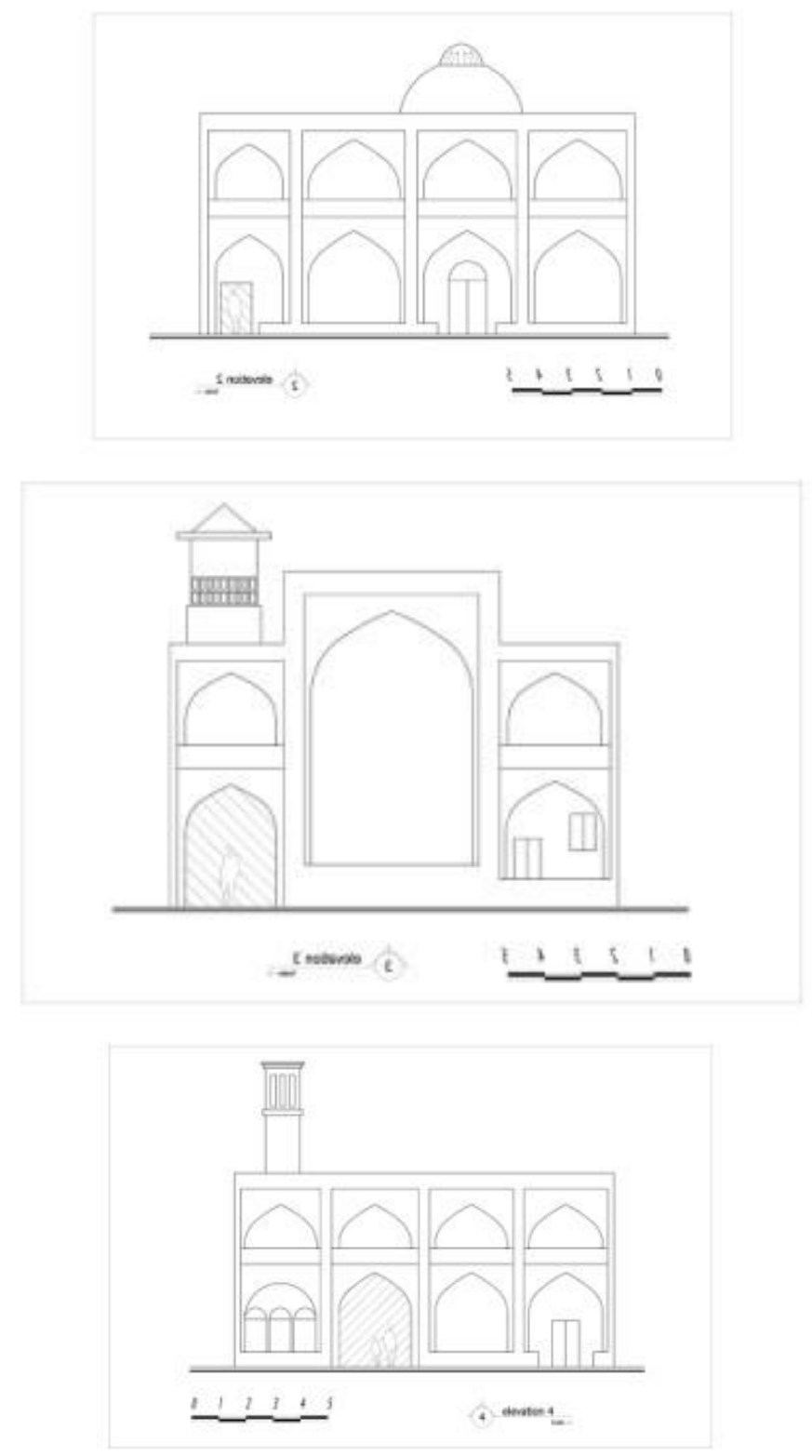

Fig (9) Jahl Dakhteran Hussaini: A horizontal plan and a sector perspective of the Hussaini, showing the its coverage and the air unit attached to it. (By the researcher)

\section{IV.3.5 No Abad Hussaini: نو آباد حسينية}

It is located in Nain city in Doctor Shariati Street in No Abad locality, dating back to the Qajared Age. It is distinguished from the other Hussaini by being internally divided into two sections (Fig, 10), one open and the other covered. The open section was designed in a rectangular horizontal plan centered by a spacious court ( Fig.10), in which the northern part is occupied by a lamp with an octagonal horizontal plan. The southern side of the court has an iwan that opens completely to the court, while the eastern and northern sides are occupied by a group of entrances, some of which are opaque and the others lead to extensions that serve the Hussaini function. As for the western side, its southern part is occupied by an edged entrance that leads to the covered section of the Hussaini, with an octagonal horizontal plan, in which each of the eight sides opens completely to the centered octagonal part that is covered by a dome with a lantern. This Hussaini is distinguished for such a creative design that serves for condolences ceremonies in summer and winter. 


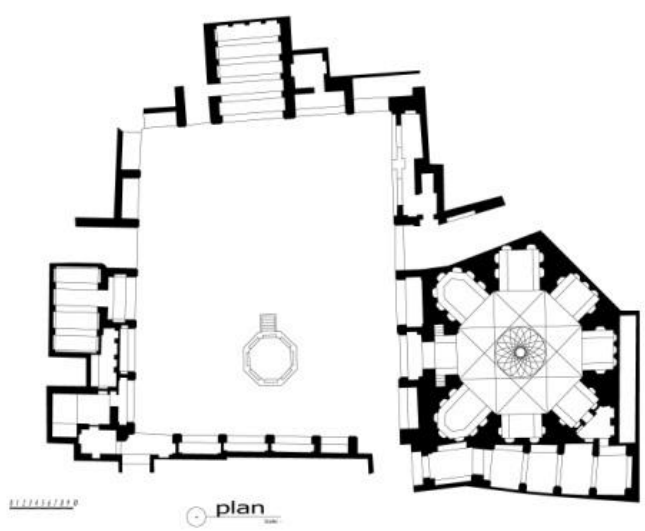

Fig (10) A horizontal plan of and a sector perspective of No Abad Hussaini. (By the researcher)

\section{The Second Pattern: It Follows Religious Sectarian Complexes:}

In such pattern, the Hussaini is one of the units constituting the complex that consists of a mosque, shrine, or imam Zadh, or has several units as will be seen in Haronih Complex, Shah Zadh Complex and others, in which such extensions are subsequent or prior to the Hussaini establishment.

\section{V.1 Iwan Style:}

It's contain from four Iwan perpendicular

\section{Vارونية حسينية : Haronih Hussaini [18]}

It follows in its design Haronih imam Zadh in Haronih area in front of Juma Masjid of Isfahan, facing Ali and Hajji Hassan mosques, dating back to the Safavid Age, while the origin of imam Zadh establishment dates back to the Seljuk or Ghaznavi Age. Some assign its establishment to Haron bin Ali, one of the ancestors of Imam Ali (9.P. 360), and was renovated at the age of Shah Ismail, and it was said that it was renovated again at the age of Shah Tahmasp by Dormesh Hussein Khan Shamlo دورميش حسين خان شاملو in 918-938 A.H. / 15121531 A.D. (10: S2,P. 221), (11. P. 221), (12. P. 509). The Hussaini occupies one of Imam Zadh sides, as it consists of a group of extensions of a school and a shrine, in addition to the Hussaini and Imam Zadh. Thus, it is considered a religious sectarian complex (Fig. 11). It is entered through the court through two entrances, and internally, the Hussaini is a rectangular horizontal plan, connected at some sides by side chambers, some of which open to the plate. Its walls are decorated with flags and badges.

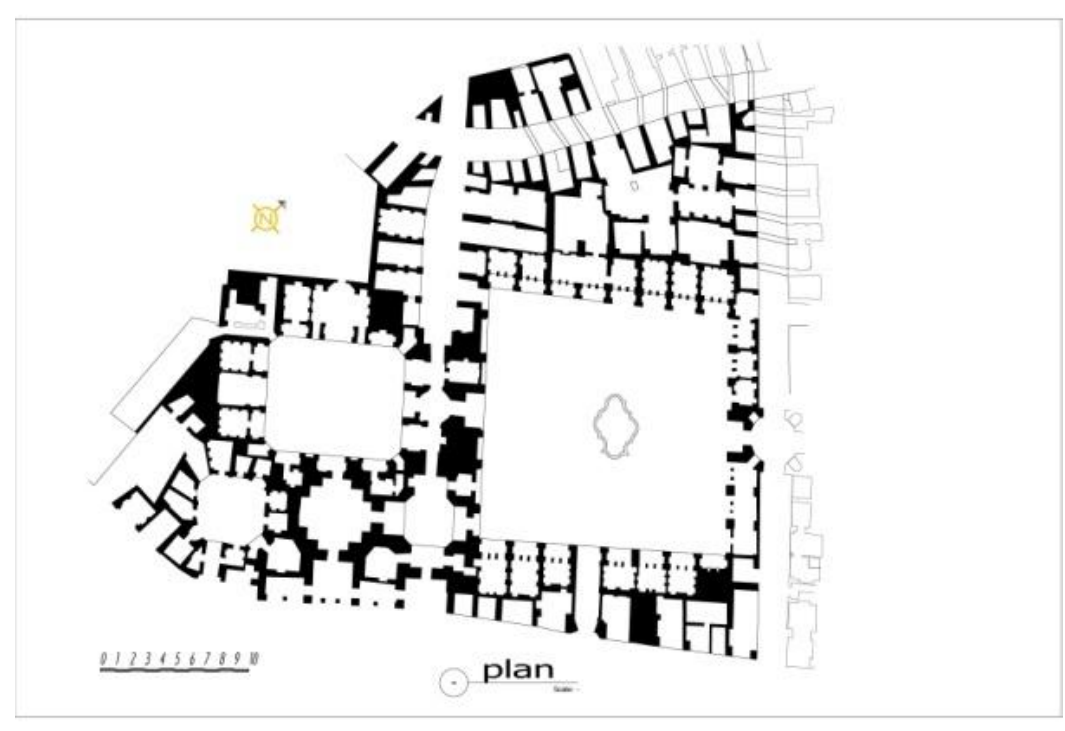

Fig (11) Haronih Imam Zadh Hussaini: A horizontal plan of Haronih Imam Zadh Complex, showing the location and design. (By the researcher) 


\section{V.1.2 Imam Zadh Darb Imam Hussaini: امام زاده درب امام حسينية}

It follows Imam Zadh Darb Imam Complex in Isfahan, dating back to the Safavid Age. It has a very long rectangular horizontal plan, in which the western southern side is occupied by a small iwan that does not fit with the spacious court, leading to the architectural complex of Imam Zadh (Fig.12). The rest of the sides are occupied by opaque entrances with edged plain sides.

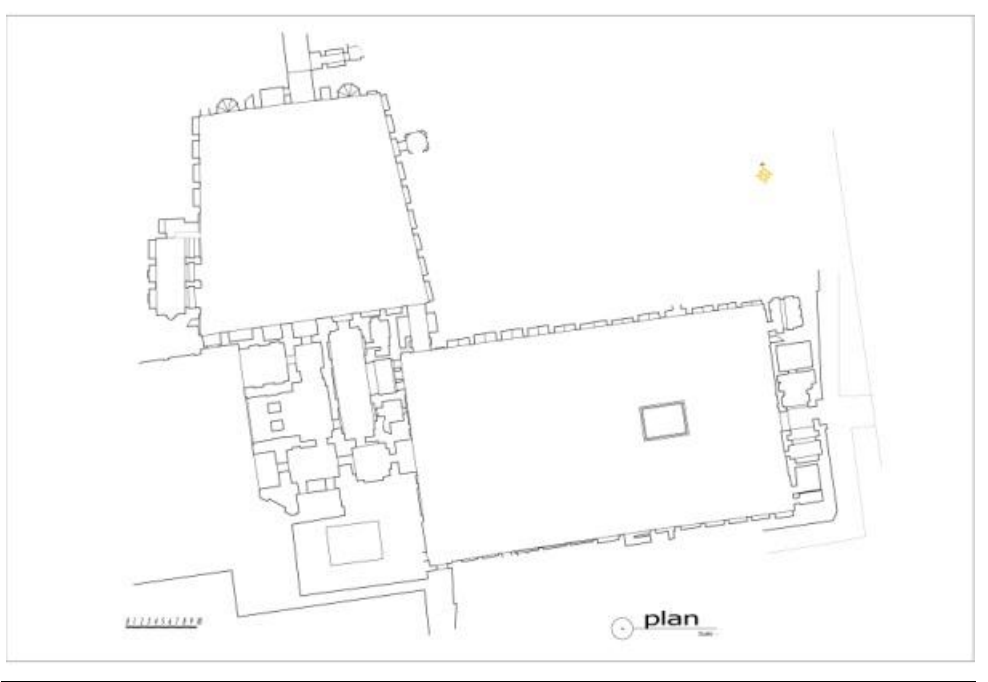

Fig (12) Imam Zadh Darb Imam: A horizontal plan of Darb Imam Zadh Complex, showing the Hussaini design attached to it. (By the researcher)

\section{V.1.3 Mader Shah Zadh Hussaini: مادرشاهز اده حسينية}

It follows in its design Mader Shah Zadh Hospice, located in Takht Folad area منطقة نخت فو لاد Isfahan, dating back to the Qajared Age. The horizontal plan of the Hussaini is a rectangle, in which the western southern side is occupied by an iwan that is divided into three linear sections, the widest of which is the middle one (Fig.13). The rest of the sides are occupied by opaque entrances that open to the court with edged sides, but they are plain. On the other hand, the eastern northern side is occupied by a group of chambers that open to the court, and the hospice court has a lamp of octagonal horizontal plan.

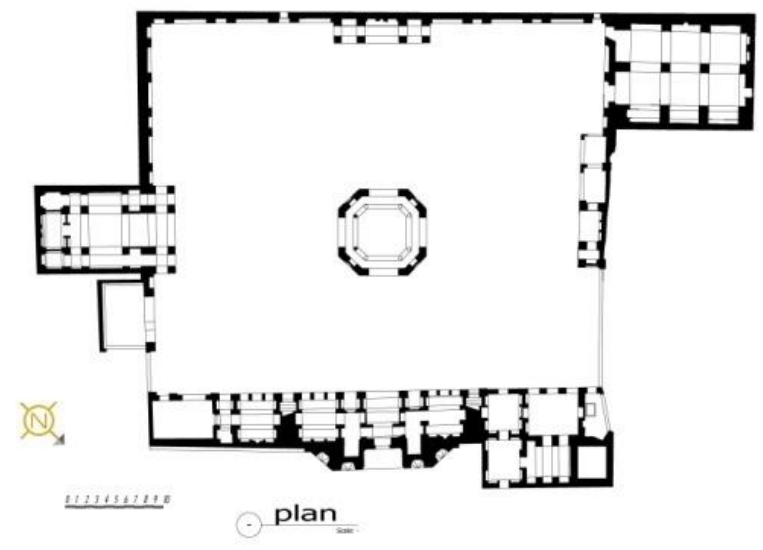

Fig (13) Mader Shah Zadh Hussaini: A horizontal plan of the Complex, showing the Hussaini design attached to it. (By the researcher)

\section{The Third Pattern: Covered Hussaini Without A Court:}

This pattern has a horizontal plan of a centered covered court, in which the whole Hussaini is covered. Due to the width of the ceiling that is, in most cases, completely covered, the architect uses wooden pillars, covered by textile at times of ceremonies, since the fall of its original ceiling due to age as will be seen in Dolt Abad Hospice. 


\section{VI.1 Shamseya Hussaini: شمسية حسينية}

It is located beside Shams Abad School in Isfahan, dating back to the end of the Safavid Age. It is distinguished by two features; the first is that it is a covered Hussaini without a court, as it is directly entered through an opaque entrance leading to an octagonal shaped corridor that opens to a spacious area of a horizontal plan consisting of eight sides. The Hussaini is currently roofed by textile covers, and it is completely renovated following its old pattern (Fig.14).
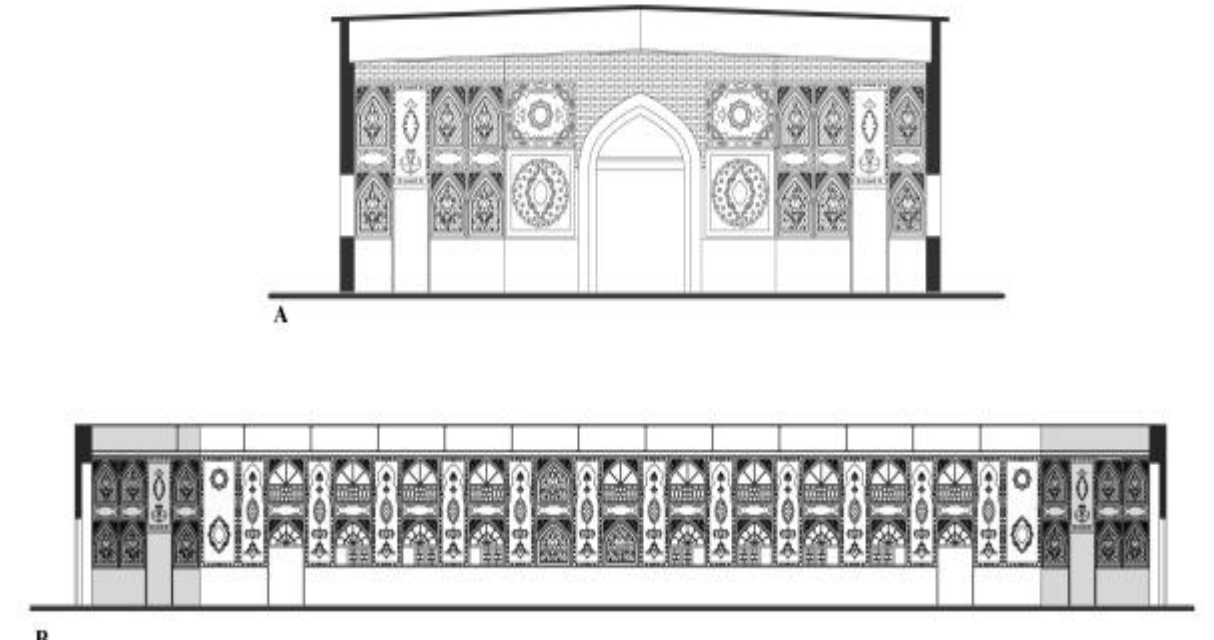

B

Fig (14) Shamseya Hussaini: A. A horizontal plans of the main interface, B. A vertical plan of one of the sides, showing the linear divisions and entrances in the Hussaini sides. (By the researcher)

\section{VI.2 Dawlat Abad Hospice: تكية دولت آباد}

It is located in the western southern side of Shams Al Emara Building,شمس العمارة in the eastern southern side of Kakh Kalstan كاخ كلمتان Tehran, built in 1284 A.H. (13. P. 287, p. 293). although in the references and resources it was described as a hospice, it was initially established to function for condolences ceremonies and other Shi'a sectarian celebration [18]. Shah Naser al-Din ordered the expansion of this hospice to the maximum, due to the narrowness of the other Hussaini in Tehran. In fact, many complaints came on such Hussaini, for women were unable to stand beside men for being overcrowded. That is why the hospice was designed on a circular horizontal plan of a diameter of $600 \mathrm{~m}$ and height of $24 \mathrm{~m}$ (14.p. 7). It consists of four floors, with a stolen floor that appears from the hospice external interface (15: S1, p. 85). The first floor was for the ministers and state rulers, while the second floor was for women (Pic. 1), in which one of its parts has an opaque entrance like an iwan and made higher and more spacious for the Shah. As for the third floor, it was for those who participated in acting and playing instruments and more (16. P. 139). The hospice ceiling was wooden and made of two layers, but it cracked and collapsed. Thus, a movable ceiling was attached to the hospice, as the architect added around 12 arches of metal and wood to be covered in textile during ceremonies. This was in an attempt to lighten the burden on the hospice architecture due to its spacious diameter. As a whole, it is a mixture of the European influences that are obvious in the building design, like that of Verona Theatre in Italy (17. P. 572, p.576), (13. P. 293, p. 294). In the hospice design, the influence with Roman theatres is obvious, as Naser al-Din Shah Qajar considered it as the best model to be followed in Hussaini architecture, as it is distinguished by its circular horizontal plan and a group of identical terraces that help in serving the theatre function and accommodate a large number of spectators. This is similar to the Hussaini function, as it requires a spacious area for condolences ceremonies and to act the scenes of al-Hussein death. 


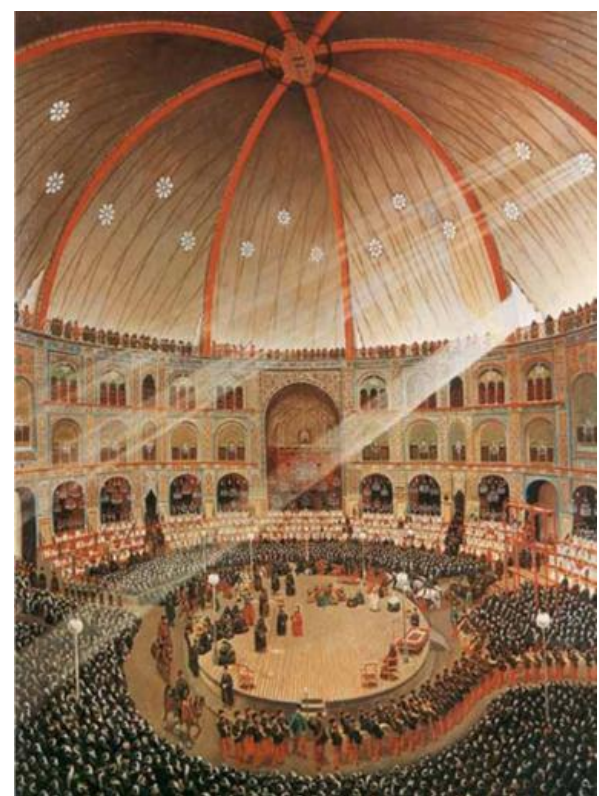

Picture (1) Dawlat Abad Hospice design, with its several floors and being roofed by the dome with wooden arches $(13$, p. 145)

\section{An Artistic Study Of The Stable And Transferred Decorative Elements On Iranian Hussaini In The Safavid And Qajared Ages:}

In addition to the artistic elements transferred of weapons, spears and more, the Hussaini have other tools used during the ceremonies, like black incense to perfume the place and palm trees to refer to the house family (6.p. 158). Also, there are words and statements of specific connotations used in condolences like "Answer Allah's Will", which is said seven times in appeal to al-Hussain. The symbol of the hand is found as well, not relating to push envy away but to applause for Imam al-Hussain, announcing the support of the condolence people to al-Hussain as Imam (4.pp. 70-71). In the Hussaini, black textile and flags are hanged for lamentation, relating to the tents of al-Hussain and his family in Karbala War Square. People who follow alHussain wear white, green and black, while his enemies wear red (11.p. 139), on which poetic quotations are written from al-Hussaini epic on sorrow and hardship. Such textile is known as the painting, and mostly the poetry of Mohtashem al-Kashani محتشم الكاثاني is written on it [19]. The Hussaini has a pan that relates to the golden pan tomb [20], like the one in which al-Hussain's head was put in it, preceded by Yahia bin Zakaria alSedik يحي بن زكريا الصديق There is also a spear referring to spear top tomb, on which al-Hussain head was raised before being killed, a plate referring to the plate tomb, and inside the Hussaini court, there is a high bed made of wood and straw of one meter height on which the condolences ceremonies are done. There are swords, truss and various martial tools reflecting al-Hussain's murder day, through which the way he was killed is acted (Fig.15, 16 ) (pic.2).

In the Hussaini, there are artistic shapes of certain meanings and symbolic representations put on spears, and are usually made of copper, like an apple, a pear, and a pomegranate, each symbolizing a story of connection between al-Hussain and his grandfather the Prophet (pbuh) (18. P. 222). There are drawings of peacocks on copper spears [49], symbolic of heaven angels and eternal happiness [21]. On these spears, there are decorations of a lion that symbolize Asad Allah Ali bin Abu Taleb (the Lion of Allah). 


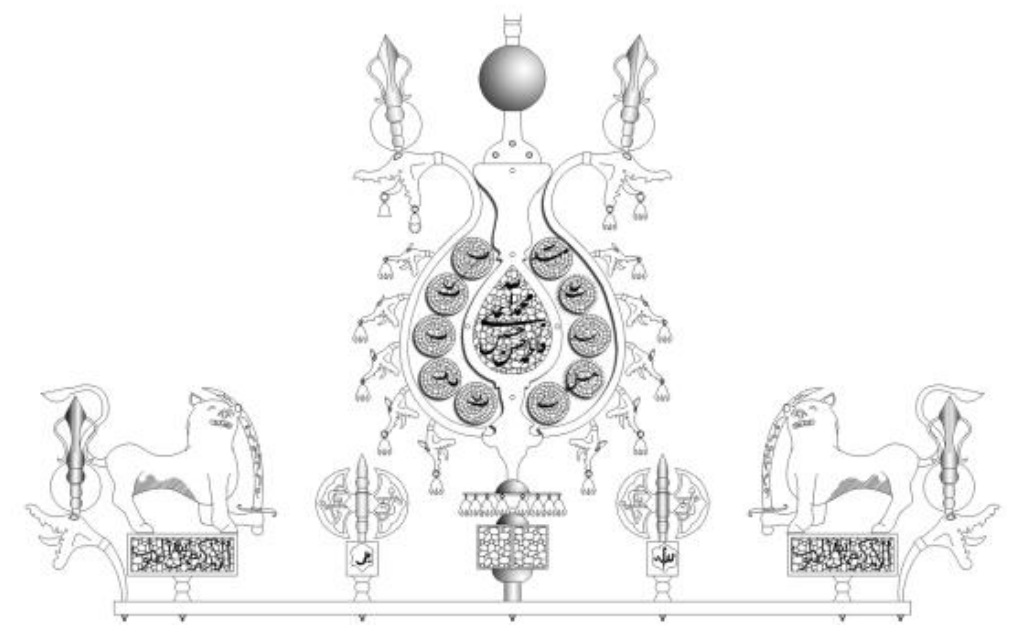

Fig (15) One of the holders spreading inside the Hussaini, on which the names of Fatima, Ali, al-Hassan and alHussain appear, beside the Quran verse: "Not with the remembrance of Allah do hearts find rest". The spear side is decorated with lions holding swords, symbolizing Ali God bless him, along with drawings of snakes and more. (By the researcher)

The lions' decorations are known from the Sasanian art in Iran, which are accompanied by decorations of snakes with bells hanging from their tongues. The snake was Adam's servant in heaven, but participated with the peacock in Satan's entrance to heaven leading to Adam's fall down to earth (19. Pp. 160-164). The snake was the best looking and highest standard of animals in heaven, before falling to earth [22]. In fact, since the oldest of ages, man has attached it to force and strength, and gave it magical features and mythical hidden powers [23]. That is why man worshipped it throughout ancient history, becoming related to good and evil together (19. p 194). On these spears, the snake may symbolize protection and evil, and it is also viewed as the power that spreads order and justice in the universe (20.pp. 73-74). All this relates to al-Hussain, who sacrificed himself for justice and the defense of mankind (Fig.15, 16) (Pic. 2).
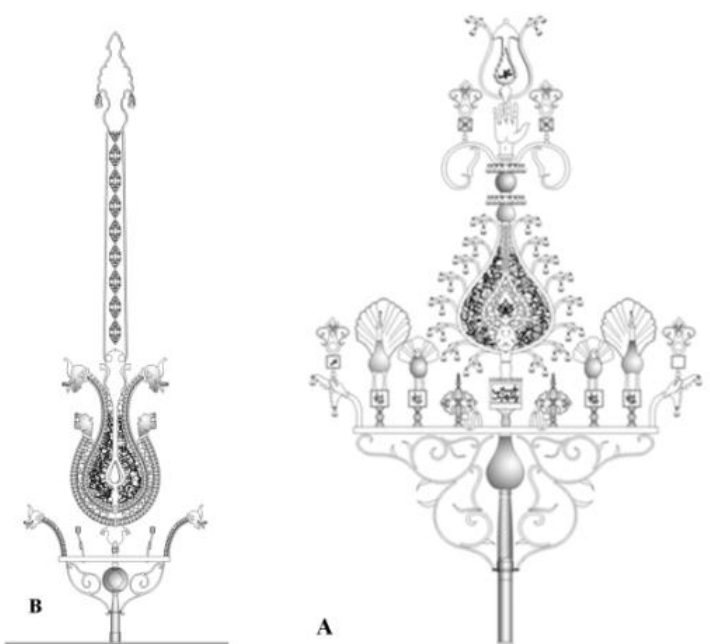

Fig (14) A. Drawing for one of the spears that carry decorations of peacocks and snakes, along with the hand and some other symbolic decorative elements. B. The sword head that refers to Ali's sword that ends in snake heads, and its handle also is surrounded by snake heads for protection and care. (By the researcher) 

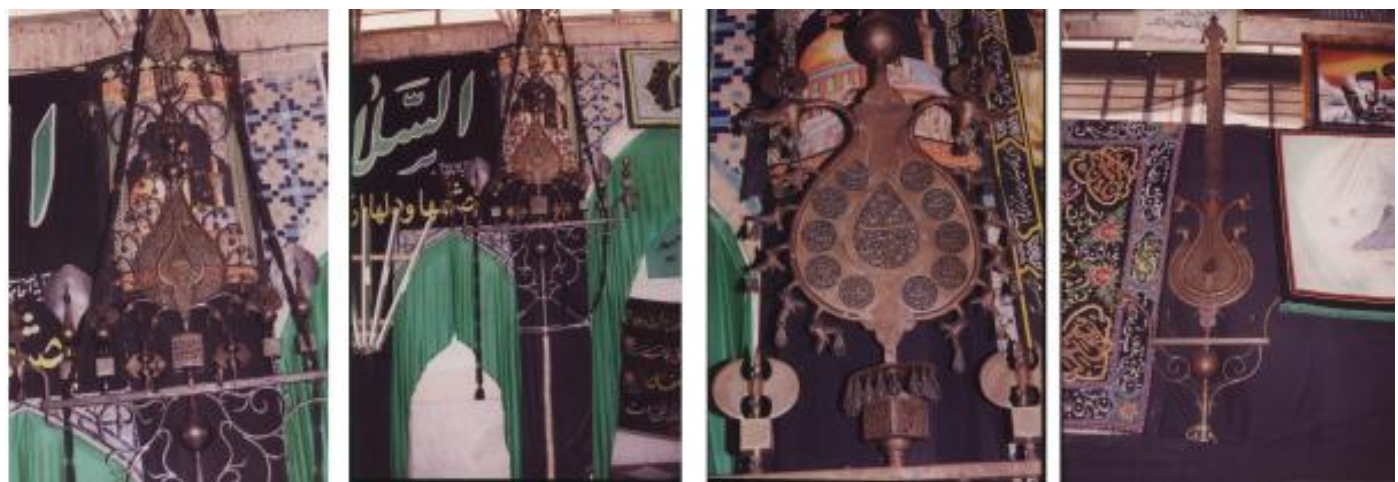

Picture (2) Samples of the artistic units and elements inside Haroni Hussaini (By the researcher)

\section{Conclusion}

1. Although the first appearance of the Hussaini architecture in Iran was in the Safavid Age due to the dominance of the Shiites doctrine, the country witnessed a leap in such architecture in the Qajared Age, as they spread inside the big and small cities at the time of Karim Khan, Naser al-Din Khan and others. This is in contrast with what was found at the age of the Qajared family of scientific heritage that is supposed to be used in teaching and training academic cadres that specialize in teaching the Shiites doctrine. This can be made up for due to the dominance of spirituality over science in the Qajared Age, and Prevalence of myths instead of scientific methods; whose imams used to turn the people against the state.

2. The total contrast between the design of the mosque and that of the Hussaini, as the latter was not divided except by a number of extensions and chambers that open from the inside. Thus, they did not occupy a space of the Hussaini court, as in its establishment, they took the space into consideration and the lack of columns or pillars. Also, Hussaini buildings were covered with cellars or flat ceilings. On the other hand, the horizontal plan of the mosque consists of a centered court in the middle of four iwans, connected through corridors, in which the mosque iwans and corridors are covered by domes or cellars.

3. It is clear to those who follow the Iranian Hussaini architecture design that most of the time a well is attached to it from the outside to provide water to the people coming for condolences, and as it also represents the Shiites thought that values water, since the master of the martyrs of heaven died deprived of it.

4. Iranian Hussaini is distinguished by its several main and subsidiary entrances, that may reach six entrances completely and directly opening to the court, which helps in serving the function of the Hussaini.

5. One of the Hussaini entrances is distinguished by being covered with a high dome centered by a lantern. In fact, this unit appeared in most of the Hussaini under study. Although this entrance is not distinguished by an architectural feature, the addition of the dome with lantern, which was not common in Iranian religious architecture in general earlier, shows that this was considered the main entrance of the Hussaini.

6. The design of the Hussaini was appropriate for its function, as it was distinguished by some features, as: Spacious court, without being occupied with any architectural unit except very rarely

- Several entrances, directly designed to open to the court

- The architect tried to follow the designs of the Safavid and Qajared mosques and schools, but despite this and due to the influence of functionality over design, many of the entrances that open to the court in the Hussaini sides were opaque for not being used. This means that, through this design, the Iranian architect preserved the external familiar appearance, but did not functionalize the added units to his architecture.

- The architect took into consideration the rotation of Moharram month throughout the year, for which there must be roofed spaces for protection from the cold of winter. Yet, almost half the Hussaini space was left as an empty court without any architectural element or unit.

- It is also noticed from the horizontal plans of Hussaini in Iran that it was not directed towards qiblah, as it was not for praying. This is apparent in the fact that even the main iwan was not in the qiblah direction, especially in the separate Hussaini, as a small mosque "Namaz Khana" was attached to it to serve the function of the mosque for the five prayers. However, the opposite is found in the Hussaini buildings attached to religious complexes, as the architect directed it towards the qiblah, for serving several functions in addition to being attached to religious buildings in which prayers were established.

Notes:

(1) It is a type of sectarian buildings in which condolences ceremonies are held for the Shi'a, (17. p.82). It was known by Prof. Sheta (21. P. 972) as "the hospice in which the holy Rawda روضه is established, and the religious ceremonies are held" (21.S1, p.972). The Hussaini buildings are known in some nooks as the public hospices, zinnia زينية, and then the cultural (3. p.101). 


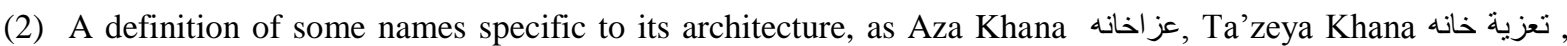

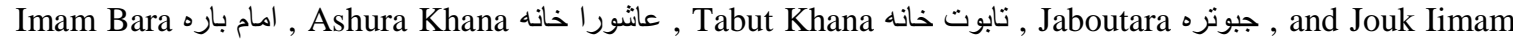
Saheb جوك امام صاحب. Such names differ with the province of establishment, and most of the Hussaini buildings have a personal nature not following the government, in contrast to the mosque. In fact, some believe that they were established in provinces for this purpose, as the state is Sunni, while there are a group of Shi'a in it, (22, p.4) (23. P. 32).

(3) The definition of hospice: it is the residence place of the monks and Sufi, similar to the architecture of khanqah, $(24$, p.93) . Far mentioned that it is the place, in which the Shi'a sectarian ceremonies are held, (17. p.62). This means that it serves both functions, unlike the Hussaini that is for condolences ceremonies only. Accordingly, it obviously and clearly differs in its architectural design from hospices. Despite this, the hospices played a major role in condolences ceremonies and lamentation as well, as in Moharram, it is specialized in doing so,( 18. pp.221-222). The hospice is thought to be "the second moral base after the mosque for Mmuslims, especially Shi'a, as it is the place where the condolences ceremony for the Master of Martyrs is held, and it is directly connected with the old performances held at the Byshdayn Age", (25 p.69). At the beginning, Hussaini buildings and zeinaat were built beside the hospices, then the hospice itself was transformed into a Hussaini to hold the condolences ceremony only, abandoning its initial function of serving as a residence for the Sufi and poor, (23. pp.22-23).

(4) It refers to a piece of land, a building, khanqah, or the sectarian architecture used as a shrine or a tomb of a sectarian or religious figure. The origin of the term refers to Imam Zadh shrine, thus relating to the ancestors of the Shiites Imams. Such buildings are decorated with decorations of sectarian connotations, (17. p.38) (26. P.338).

(5) Khanqah خانگا: a building for dervishes of Sufism for worships and residence, (17. p.85). It is a religious architecture, not specific to Shi'a only, but spread in the Islamic world. The term khanqah arrived to Iran with Sheikh Safey al-Din al-Ardabili, who had a khanqah in Ardabil established by Taymour Lenk. Historians differ on his doctrine; some believe he is Sunni, while others relate him Ali, and the first to refer to this was Shah Tahmasp in the series of the ancestors related to him and that transcend to his family, (27, S.2, pp.340-360), (28, p345), (29, p.39)

(6) It is the cemetery for imams, their pure children and the main Shi'a masters. (17. p.27).

(7) The prayer is an open spacious area for the prayers of the two feasts, and it usually found on the borders of the cities, (6. p.157).

(8) The sectarian places in Iran are also known as all the buildings established with a religious sectarian belief, like mosques, holy areas, religious schools, Imam Zadh and more, (17, p.27).

(9) It is the place in which condolences ceremonies are held, (26, p.666), in which there is crying, weeping, wailing and all the lamenting ways that Shi'a show in the Master of Martyrs al-Hussain epic. It starts from the beginning of Moharram, since al-Hussain's leave to al-Najaf until Ashura Day, which is known as the major pain day. The great fear day is Ashura that witnessed the slaughter of al-Hussain, and from the eleventh till the thirteenth are days of depriving al-Hussain of the right to be buried, as he was left dead on the ground for three successive days. Then, comes the fortieth day that witnessed burying him starting with his holy head. For more information on crying, weeping and wailing, (3. pp.70-72).

(10) The Shi'a assign several ceremonies to al-Hussain, God bless him, as they have Hussaini calligraphy, Hussaini tune, Hussaini love, Hussaini passion, Hussaini poetry, Hussaini sanctuary, Hussaini Ashura, and Hussaini condolences. All these ceremonies and activities are attributed to al-Hussain, for his state as the Master of Heaven Martyrs and for being the son of Fatima al-Zahraa daughter of Prophet Muhammad (pbuh), (11. p.126).

(11) Some historians mentioned that there is a relation between the establishment of Hussaini and what was known in some Old Persian religions as the Alipidashyh البيداشية , as there were common ceremonies among both. For more information (25. p.69).

(12) "The crying eye is the source of Allah's blessing", as crying over Abu Abdullah crisis is a good deed, as all who is in the heaven and earth cried for him, ( 30 , p.45). Imam al-Reda told one of his companions "....if you will cry over something then let it be al-Hussain bin Ali bin Abdul Moteleb, as he was slaughtered like a ram",( 30, pp.312-313). He also said: "Moharram is the month in which people before Islam forbid killing, so they shed our blood, violated our sacred, swore at our ancestors and women, started fire in our houses and destroyed all our belongings. They did not take into consideration Allah's Prophet forbidding of anything concerning us. Al-Hussain day made our eyes swell, shed our tears, humiliated our master on a land of sorrow and plague, and gave us the heritage of sorrow and plague till our death, so for al-Hussain shall we all cry, as crying over him removes our major sins". Al-Hussain said: "I am the killed for a lesson, and who ever remembers me shall cry", and al-Sadiq said: "All anxiety and crying is hateful, except that for al-Hussain", (30. , p.283, p.279) , (3, pp.70-71).

(13) For more details, see (31, S.1,), ( 32, Vol.2). 
(14) This hospice was brought down in 1372 and was located behind the National Bank near the grocery market, (32, pp.35-44).

(15) It is known in Persian as gol-daste, (26. p.853). this architectural unit is specialized for prayers and calling for praying, which is the element that is normally found in Iranian mosques due to the rare existence of minarets that are only found in major mosques. This gol-daste has to observe the widest major streets and the populated alleys or the streets linking between commercial areas.

(16) This term is used to refer to the architectural units that look like a chimney, having several ventilation openings with various models in civil buildings, especially in public markets. The oldest of these is Karman in Bazaar A'zam, Badqeer Dawlat Abad Beyzid, and Badqeer Jepqy in Sirjan, and the several ventilation openings are found in Bandar Abbas, Larestan, Qashm and in all Iranian cities in general.

(17) Historically proved under number 202, (12 p.510). Its school is known as Meraza Shah Hussain, ( 10 , S.2, p.200).

(18) At the beginning, in referring to Hussaini and their titles, it was noticed that there was a mix between Hussaini titles and some other sectarian buildings like the hospice. Yet, historically and functionally, this hospice was established and specialized in condolences ceremonies and more.

(19) He is the Sun of Poets (Shams al-Shoaraa) Mohtashem al-Kashani, who lived at the beginning of the Safavid Age and died in 996 A.H. / 1587 A.D. All his poetry was for lamenting al-Hussain, God bless him, and Prophet Muhammad (pbuh) family,( 3. p.405) .

(20) Mentioned in Majlesy, on the three fruits that: "al-Hassan and al-Hussain in their youth with Prophet Muhammad and Jibril playing around the Prophet, were given an apple, quince and pomegranate, and they gave them to the Prophet who asked them to give the fruits to their mother Fatima. They all ate together and returned to their origin state, until the death of Prophet Muhammad (pbuh), and al-Hussain said: "there was no change back then in Fatima days. When she died, we lost the pomegranate, and the quince and apple remained during Ali days. Then, when Ali died, we lost the quince and only the apple remained as it is even after the death of al-Hassan who was poisoned. But, I was banned from drinking water and whenever I was thirsty, I would just smell the apple and the thirst would be gone. But, as the thirst was unbearable, I took a bite and I was sure I was finite". (30, p.49) This was narrated by Ali bin al-Hussain an hour before his death, and it is believed that Karbala land smells like apple in the morning, (3. pp.191-192).

(21) The shapes and decorations of peacocks spread in Iran and were attached to all Iranian applied arts. It is noticed that this element appeared in the Islamic Age in Iran since the Seljuk Age till the Safavid and Qajarite, (34. pp.179-180).

(22) It was said on al-Hassan God bless him, "Adam was fallen in India, Eve in Jedda, Satan in Destiman in Basra, and the snake in Asbahan", (35 p.22) . (36. S.1, p.26).

(23) It was said on behalf of al-Qortoby in the interpretation of Ghafer Verse, by Kaab al-Ahbar that he said: "When Allah created the throne, he said: He did not create anyone better than me and was moved by greatness, so Allah surrounded him by a snake of seven thousand wings, in each wing seven thousand feathers, in each feather seven thousand face, in each face seven thousand mouths, and in each mouth seven thousand tongue coming out for praise as much as rain drops, tree leaves, stones, days and all angels. The snake then leaned and the throne half leaned on it, making him modest”, (36. S.1, p.252).

\section{References:}

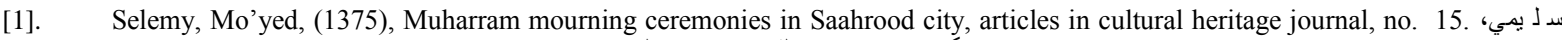

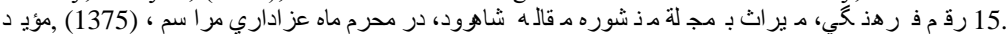

[2]. Pour, Anasery, J., (1383), Shi'a effect on buildings, places of religious and visiting in Iran, a Shiite studies ,second season, No. 7

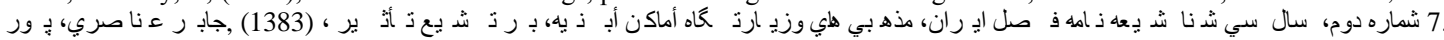
Mohdethy, Jawad, (1997), Ashura Encyclopedia, translated by Kahlil Zamel al-Esamy, Issue 1, Beirut.

[4]. Altestry, Jafaar, (1993), Hussaini Days, translated by Ibrahim Refa'a, Issue 1, Dar al-Murtada, Beirut.

[5]. Manshy, Iskander Bek, (1377), The History of the Abbasid Aray World, edited by Muhammad Ismail Radway, Part 3, Tehran

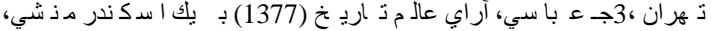

[6]. Tosli, Muhammad, (1383), Hussaini, Hospices and Sanctuaries, published article in Iranian architectural book of Islamic role, collected by Muhammad Youssef Kayany, Tehran.

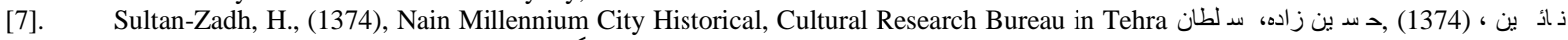

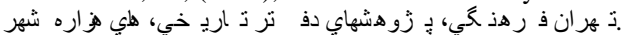

[8]. Kayany, Muhammad Youssef, (1368), Iran Architects, Tehran

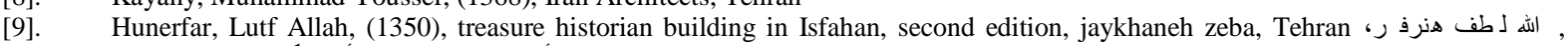

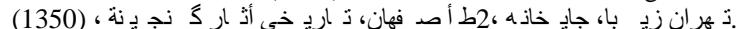

[10]. Abtahi, Mir Sayyid Hajjah unitary, (1418), Hoza elmiya of Shiism in Isfahan along the history, 3 volumes, Isfahan

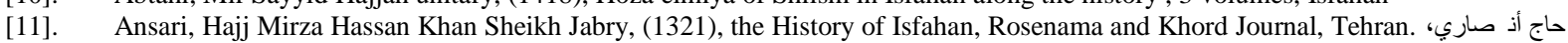

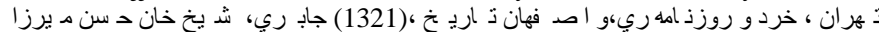

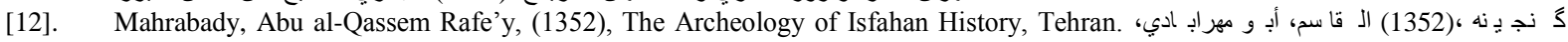
ت ذيران اصد فهان، ذن اري خي

[13]. Z Zka', Y., (1349), History of the Imperial Citadel buildings in Ark and Tehran Golestan Palace, published by the National Heritage

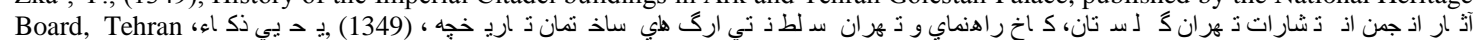
مد لي. 


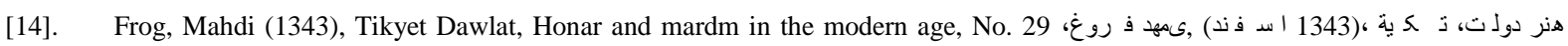
29.

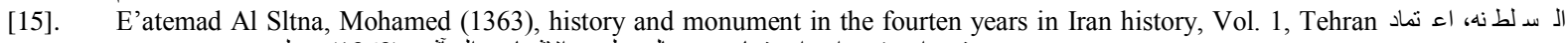

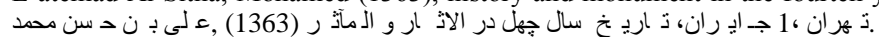

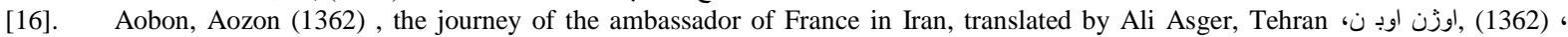

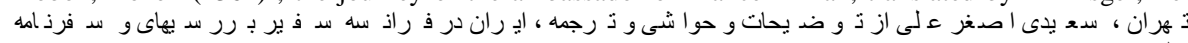

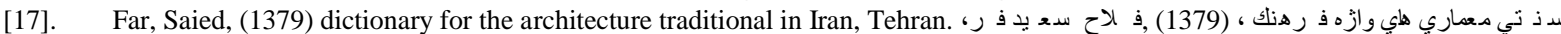
ت تران اي ران،

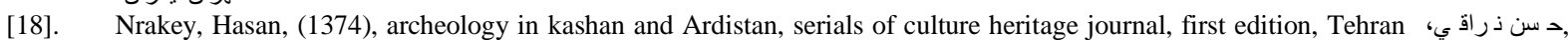

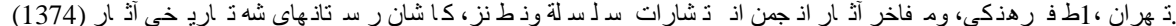

[19]. Yassin, Abdul Nasser, (2006), Religious Symbolism in Islamic Decoration (A study of the Islamic art metaphysics), Cairo

[20]. Anas al-Wojoud, Thanaa (1999), The Snake Symbol in Arab Heritage, The General Institution for Culture Palaces, Zakerat alUmma 11, Cairo, Issue 2.

[21]. Sheta, Ibrahim al-Dosouky, (1370), The Major Persian Dictionary, 3 Volumes, Cairo.

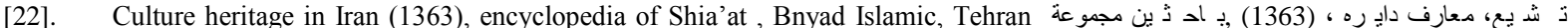
طاهر إسدامي بـ ذن ياد.

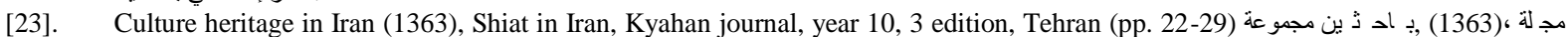
22-29

[24]. Khoury, Amin, (1894), Ottoman Companion, Faculty of Arts publishing, Beirut Abbasy, Mhedy, (1371), the history of Tkyiet and

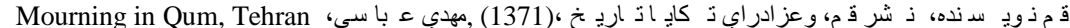

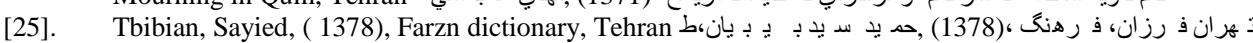

[26]. Zambawr, Edward, (1980), Glossary of Ruling Families and Ancestors in the Islamic History, collected by Zaki Muhammad Hassan and Hassan Mahmoud, S.2, Beirut

[27]. Phalsaphy, Nasr Allah, (1989) Iran and its Foreign Relations in the Safavid Age, translated by Muhammad Fathy al-Rayes, Culture for Printing and Publishing, Cairo

[28]. Al-Khouly, Goma'a, (1976), The History and Civilization of the Safavid, Cairo. Al-Alama Majlesy, (1403), Seas of Light, Beirut

[29]. Ministry of building and accommodation, |(1365), Urban design principles and methodology of residential in Iran, vol. 1, Tehran

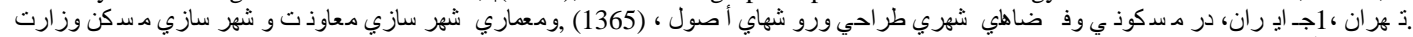

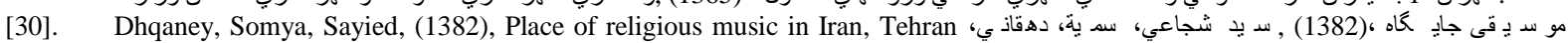

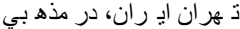

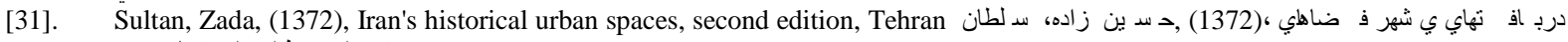

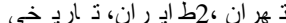

[32]. Daneshvari, A, )1994(, A Preliminary Study of the Iconography of the Peacock in Medieval Islam, the Art of the Seljuq in Iran and Anatolia, California.

[33]. Ibn Katheer, al-Hafez Emad al-Din (1999), Tales of Prophets, edited by Abu Ammar bin Abdullah, Issue 3, Cairo

[34]. Al-Demeiry, Kamal al-Din, (d.t.), The Major Life of Animals, Part 1, in its notes The Mysteries of Creatures and Animals and the Oddity of Beings, Imam Zakaria bin Muhammad al-Qazweeny, Arab Heritage Revival publishing, Beirut. 